\title{
HIGH SENSITIVITY METHOD FOR DETERMINATION OF TRACE CURCUMIN IN THE AQUEOUS PHASE
}

\author{
YA-FEN CHANG, CAI-PING CHEN, HAO WU, LI-MING DU*, REN-NA YI, XU JING, YUN-LONG FU \\ Analytical and Testing Center, Shanxi Normal University, Linfen, Shanxi 041004, P.R. China
}

\begin{abstract}
A new ionic liquid (IL) based micro-extraction method was developed for the spectrophotometry and spectrofluorometry determination of curcumin in curry products. ILs can effectively extract curcumin from aqueous solution which were used instead of large-scale organic solvents to reduce environmental pollution and production cost. Results show that the fluorescence of curcumin is considerably enhanced in 1-hexyl-3-methylimidazolium hexafluorophosphate $\left([\mathrm{Hmim}]\left[\mathrm{PF}_{6}\right]\right)$. Under optimized conditions, the absorbance of curcumin is proportional to the concentration of curcumin in the range of $18.4 \mathrm{ng} / \mathrm{mL}$ to $494 \mathrm{ng} / \mathrm{mL}$, and the detection limit is $6.1 \mathrm{ng} / \mathrm{mL}$. In addition, the fluorescence intensity of curcumin is proportional to the concentration of curcumin in the range of $0.050 \mathrm{ng} / \mathrm{mL}$ to $120.1 \mathrm{ng} / \mathrm{mL}$, and the detection limit is $0.002 \mathrm{ng} / \mathrm{mL}$. Therefore, an efficient spectrophotometry and spectrofluorometry method for the determination of curcumin was established, and the actual concentration in curry products was satisfactorily determined. The content of curcumin in curry sauce were $14.10 \pm 0.40$ and $14.32 \pm 0.37 \mathrm{mg} / \mathrm{g}$ when using the spectrophotometry and spectrofluorometry, the content of curcumin in curry powder were $2.50 \pm 1.73$ and $2.75 \pm 1.40 \mathrm{mg} / \mathrm{g}$ when using the spectrophotometry and spectrofluorometry.
\end{abstract}

Keywords: Curcumin, Ionic liquids, micro-extraction, spectrofluorometry, spectrophotometry

\section{INTRODUCTION}

Curcumin [1,7-bis-(4-hydroxyl-3-methoxyphenyl)-1,6-heptadiene3,5-dione] $\left(\mathrm{C}_{21} \mathrm{H}_{20} \mathrm{O}_{6}\right.$, Figure 1) is a natural phenolic pigment obtained from the rhizome of Curcuma longa Linn. It has been reported that curcumin has many pharmacological functions, such as antioxygenation, antibiosis and antitumor $^{1-3}$. Methods such as high-performance thin-layer chromatographic

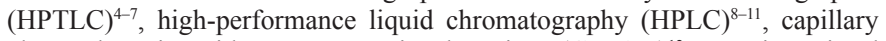
electrophoresis with amperometric detection $(\mathrm{CE}-\mathrm{AD})^{12}$, matrix-assisted laser desorption ionization time of flight mass spectrometry (MALDITOFMS $^{13}$, spectrofluorimetry ${ }^{14,15}$, liquid phase tandem mass spectrometry (LC-MS/MS) $)^{16,17}$, ${ }^{1} \mathrm{H} \mathrm{NMR}{ }^{17}$, resonance light scattering technique (RLS) ${ }^{18}$ and spectrophotometry ${ }^{19-21}$ have been employed to determine curcumin in a variety of matrixes. However, most of these methods have low sensitivity, need a large number of organic solvents or metal ions. Compared with the extensive absorption in organic solvent, its absorbance strongly decreased in aqueous solution, which precludes the determination of trace amount of curcumin in aqueous solution.<smiles>COc1cc(/C=C/C(=O)CC(=O)/C=C/c2ccc(O)c(OC)c2)ccc1O</smiles>

Figure 1 The structure of curcumin.

Room temperature ionic liquids (RTILs) are composed entirely of organic cations and various anions that are liquid at room temperature, thus, they are generally soluble in polar diluents such as chloroform and dichloromethane. RTILs are thermally stable, ability to dissolve a variety of organic and inorganic substances, miscible with other liquids, recyclable, and do not evaporate ${ }^{22,23}$, which make them considerably appealing as environmentally friendly for various fundamental studies and applications. Temperature-assisted ionic liquid dispersive liquid phase microextraction (TAIL-DLPME) is based on temperature changes, which cause ILs to disperse in the aqueous phase and increase the chance of mass transfer ${ }^{24}$. Finally, the ILs are condensed into one drop by cooling and centrifugation ${ }^{25}$. ILs have been used as alternatives for classical organic solvents in chemical processes for synthesis ${ }^{26}$, catalysis ${ }^{22}$, electrochemistry ${ }^{27-29}$, and extraction of organic pollutants ${ }^{22,30-32}$. To the best of our knowledge, the use of TAIL-DLPME combined with spectrophotometry and spectrofluorometry for the analysis of curcumin in aqueous phase has not yet been reported.

In this study, three RTILs were used to extract curcumin from aqueous solution. The best extractant and optimum extraction conditions were determined using spectrophotometry and spectrofluorometry. A new assay method for curcumin based IL liquid-liquid micro-extraction technique was then established. This assay is sensitive, simple, cheap, environmentfriendly and practical. The establishment of this method can also be successfully used for the determination of foodstuff.

\section{EXPERIMENTS}

\section{Apparatus}

Fluorescence spectra were obtained with an Agilent Technologies Cary Eclipse fluorescence spectrofluorometer (Agilent, Australia) equipped with a pulsed lamp. The slit width of the excitation and emission monochromators was set at $5 \mathrm{~nm}$. Fluorescence spectra were recorded at a scan rate of $600 \mathrm{~nm} / \mathrm{min}$. Absorption spectra were recorded with a Cary 300 (Varian Associates, America), the slit width was set at $2.5 \mathrm{~nm}$. All measurements took place in a $0.7 \mathrm{~mL}$ quartz cell at $25.0{ }^{\circ} \mathrm{C} \pm 0.5^{\circ} \mathrm{C}$. The $\mathrm{pH}$ values were measured with a pHS-3TC digital precision $\mathrm{pH}$ meter (Shanghai, China). A centrifuge Model TDZ4-WS (Hunan, China) was used to accelerate the phase-separation process. A SHA-B constant-temperature shaker (Jiangsu, China) was used to control temperature.

Reagents and Chemicals

All the reagents and chemicals used in the study were of analytical grade or the best grade commercially available. Doubly-distilled water was used throughout.

Curcumin $(\mathrm{M}=368.38 \mathrm{~g} / \mathrm{mol})$ was obtained from Tokyo Chemical Industry Co., Ltd. The stock solution $(0.368 \mathrm{mg} / \mathrm{mL})$ was prepared in acetonitrile and stored in the dark in amber bottles at $4{ }^{\circ} \mathrm{C}$, and then diluted to $1.84 \times 10^{-3} \mathrm{mg} / \mathrm{mL}$ with double-distilled water as the working solution.

The stock solutions of ILs (1-octyl-3-methylimidazolium tetrafluoroborate $[\mathrm{Omim}]\left[\mathrm{BF}_{4}\right], \quad[\mathrm{Hmim}]\left[\mathrm{PF}_{6}\right] \quad$ and 1-octyl-3-methylimidazolium hexafluorophosphate $[\mathrm{Omim}]\left[\mathrm{PF}_{6}\right]$ ) were purchased from Chengjie Chemical Company (Shanghai, China) and used as obtained (99\%). All ILs were diluted with methanol to a volume ratio of $1: 1$, and then stored in the dark at room temperature.

\section{Procedure}

Working solutions were added to a $12-\mathrm{mL}$ graduated centrifuge tube in the following order: $1.0 \mathrm{~mL} \mathrm{HCl}$ solution $(\mathrm{pH}=3.0)$ and an appropriate amount of curcumin solution (or samples). The mixture was diluted to $10 \mathrm{~mL}$ with double-distilled water and shaken well. Then, $400 \mu \mathrm{L}$ of methanol containing $200 \mu \mathrm{L}$ of $[\mathrm{Hmim}]\left[\mathrm{PF}_{6}\right]$ was added. The tubes were heated in a water bath at 70 ${ }^{\circ} \mathrm{C}$ for $5 \mathrm{~min}$. The cloudy solution gradually clarified under these conditions. The solutions were cooled on an ice bath for $5 \mathrm{~min}$ and centrifuged for $8 \mathrm{~min}$ 
at $3500 \mathrm{rpm}(1684 \times g)$. The upper aqueous phase was removed with a syringe. Then the IL phase was maintained constant at $0.3 \mathrm{~mL}$ with methanol and transferred into quartz cells for spectrophotometry determination.

During spectrofluorometry, the IL phase was dried with nitrogen flow at 1.0 bar for $5 \mathrm{~min}$ at $70{ }^{\circ} \mathrm{C}$. The IL phase was then directly transferred into quartz cells for fluorescence determination ${ }^{24,33}$. The calibration graph was constructed in the same way using the studied curcumin solutions at known concentrations.

\section{Sample treatment}

Curcumin was extracted from samples of curry products (curry sauce and curry powder were acquired in the diffirent commercial food establishment, China) according to previously reported procedures ${ }^{15}$. A total of $8 \mathrm{~mL}$ of acetonitrile was added to $1.0030 \mathrm{~g}$ of curry sauce or $1.0007 \mathrm{~g}$ of curry powder, and the mixture was subjected to ultrasonic extraction for $20 \mathrm{~min}$. The supernatants were obtained by centrifugation and then diluted 20 times with acetonitrile and then stored in the dark in amber bottles at $4{ }^{\circ} \mathrm{C}$. Curcumin content was determined by standard addition method according to the procedure described earlier. The standard addition method was conducted by adding the curcumin to curry sauce and curry powder.

Calibration of enrichment factor and extraction recovery

To evaluate the performance of the proposed method, extraction recovery was applied. Calculating extraction recovery (R) of curcumin by adding the standard solution in the foodstuff sample. Eqs. were applied for calculating recovery in aqueous phase, and foodstuff, respectively.

$$
\mathrm{R}(\%)=\frac{\mathrm{C}_{\text {sed }} \mathrm{V}_{\text {sed }}}{\mathrm{C}_{0} \mathrm{~V}_{\mathrm{aq}}} \times 100
$$

Where $\mathrm{C}_{\text {sed }}$ and $\mathrm{C}_{0}$ are the analyte concentration in sediment phase and the initial analyte concentration in sample solution, respectively, $\mathrm{V}_{\text {sed }}$ and $\mathrm{V}_{\mathrm{aq}}$ are the volume of sediment phase and the volume of sample solution, respectively.

\section{Effect of Foreign Ions}

Adding the foreign ions to the standard solution of curcumin, by measuring the change in absorbance to determination the interfere of foreign ions. The tolerance level was defined as an error not exceeding $\pm 5 \%$ in the determination of curcumin

\section{RESULTS AND DISCUSSION}

\section{ILs sensitized fluorescence}

The fluorescence increase of compounds in RTILs were first reported in $2006^{34}$, As shown in Figure 2, an methanol solution of curcumin had weak fluorescence; however, increases in fluorescence intensity was observed when it was excited in $[\mathrm{Hmim}]\left[\mathrm{PF}_{6}\right]$. Its excitation/emission wavelengths changed from $459 / 544 \mathrm{~nm}$ to $422 / 499 \mathrm{~nm}$. The sensitizing effect of curcumin in [Hmim] $\left[\mathrm{PF}_{6}\right]$ not only to be related to the special nature of $[\mathrm{Hmim}]\left[\mathrm{PF}_{6}\right]$ itself (such as viscosity, polarity, low oxygen solubility and slow diffusion processes, etc. $)^{34}$ $\square$ but also the intermolecular interactions between $[\mathrm{Hmim}]\left[\mathrm{PF}_{6}\right]$ with curcumin (such as hydrogen bonding, dipole-dipole interactions, charge interaction, etc.). In general $\square$ the maximum emission wavelength would to be a red shift when the solvent polarity was increasing, thus, when the solvent from methanol changes to $[\mathrm{Hmim}][\mathrm{PF}$ ] , the maximum emission wavelength of curcumin would have a blue shift. Because the pure $[\mathrm{Hmim}]\left[\mathrm{PF}_{6}\right]$ has the ability to sensitized the fluorescence of curcumin, so ILs phase were dried with a nitrogen flow and then transferred into quartz cells for fluorescence determination.

\section{Type and volume of the extraction solvent}

The extraction efficiencies of $[\mathrm{Omim}]\left[\mathrm{BF}_{4}\right],[\mathrm{Hmim}]\left[\mathrm{PF}_{6}\right]$, and $[\mathrm{Omim}]$ $\left[\mathrm{PF}_{6}\right]$ at the same concentration of curcumin aqueous solution were compared (Figure 3). $[\mathrm{Hmim}]\left[\mathrm{PF}_{6}\right]$ showed the highest fluorescence enhancement and maximum absorbanceof curcumin. Thus, $[\mathrm{Hmim}]\left[\mathrm{PF}_{6}\right]$ was used as the extraction solvent. Under optimal experimental conditions, the extraction recovery rate was $98.1 \%$ and the excitation and emission of the blank reagent do not affect the determination of curcumin. Therefore, the wavelengths 422, 422, and $499 \mathrm{~nm}$ were selected as absorption, excitation, and emission conditions. (a)

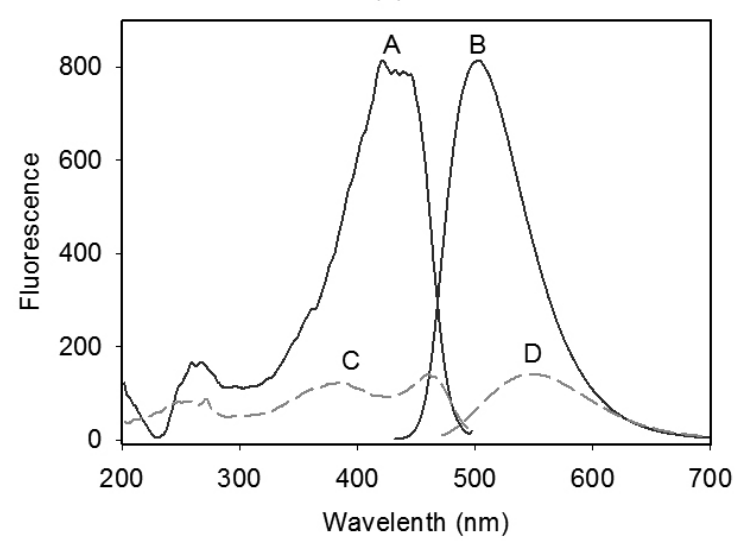

(b)

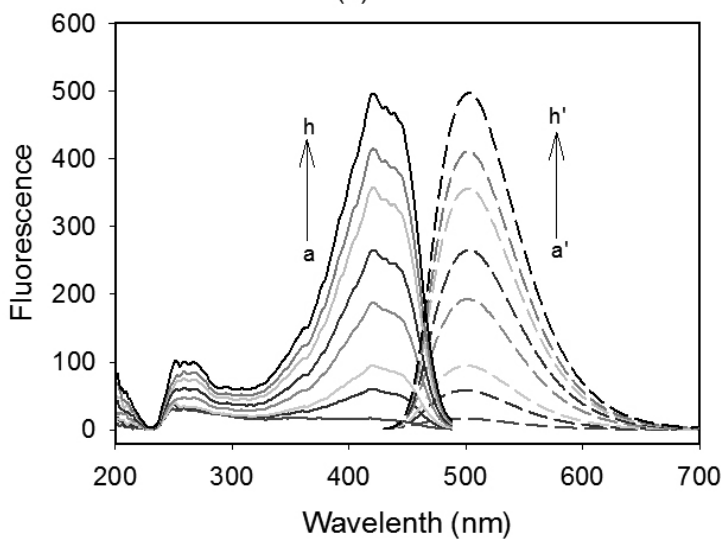

Figure 2 2(a) are the fluorescence comparison chart of curcumin in $[\mathrm{Hmim}]\left[\mathrm{PF}_{6}\right]$ and methanol solutions. The concentration of curcumin was $9.2 \mu \mathrm{g} / \mathrm{mL}$. (A) and (B) are the fluorescence excitation and emission spectra of curcumin in $[\mathrm{Hmim}]\left[\mathrm{PF}_{6}\right]$, respectively; $(\mathrm{C})$ and $(\mathrm{D})$ are the fluorescence excitation and emission spectra of curcumin in methanol, respectively; 2(b) are the fluorescence excitation and emission spectra of curcumin with various concentrations of ILs. From a to $h$ were the fluorescence excitation spectra of curcumin corresponding different concentrations, and the $\mathrm{a}^{\prime}$ to $\mathrm{h}^{\prime}$ were the fluorescence emission spectra of curcumin corresponding different concentrations. The concentrations from a $\left(\mathrm{a}^{\prime}\right)$ to $\mathrm{h}\left(\mathrm{h}^{\prime}\right)$ were $0.092 \mu \mathrm{g} / \mathrm{mL}, 0.46$ $\mu \mathrm{g} / \mathrm{mL}, 0.92 \mu \mathrm{g} / \mathrm{mL}, 1.84 \mu \mathrm{g} / \mathrm{mL}, 2.76 \mu \mathrm{g} / \mathrm{mL}, 3.68 \mu \mathrm{g} / \mathrm{mL}, 5.52 \mu \mathrm{g} / \mathrm{mL}, 4.60$ $\mu \mathrm{g} / \mathrm{mL}$.

Volume dependence was studied within the range of $50 \mu \mathrm{L}$ to $250 \mu \mathrm{L}$. The maximum absorbance was obtained when the volume of $[\mathrm{Hmim}]\left[\mathrm{PF}_{6}\right]$ was $200 \mu \mathrm{L}$, which remains unchanged with the further increase in volume. Based on the volume of quartz cell and spectrofluorometer, the settled phase should contain at least $120 \mu \mathrm{L}$ for accurate determination. Fluorescence intensity rapidly weakened when the IL volume was less than $200 \mu \mathrm{L}$. Based on this condition, the extraction volume of $200 \mu \mathrm{L}$ was adopted as the optimum volume of $[\mathrm{Hmim}]\left[\mathrm{PF}_{6}\right]$ in the present study, and the actual volume of fluorescence determination were approximately $0.17 \mathrm{~mL}$.

Effect of $\mathrm{pH}$ value

The effect of $\mathrm{pH}$ on $[\mathrm{Hmim}]\left[\mathrm{PF}_{6}\right]$ extraction of curcumin was studied in the range of 1.0 to 7.0 by adding an appropriate volume of hydrochloric acid to aqueous samples. The $\mathrm{pH}$ range used in the present study was based on the literature ${ }^{21,35}$ : curcumin was exposed to hydrolytic degradative reactions in basic media and is therefore unstable, so it is more suitable to detect curcumin in the media whose $\mathrm{pH}$ value is maintained below 7.0. As shown in Figure 4, the maximum absorbance and fluorescence intensity was obtained at $\mathrm{pH} 4.0$. However, the intensity of absorption and fluorescence decreased upon further increase from $\mathrm{pH}$ 6.0. Therefore, $\mathrm{pH} 4.0$ was used for subsequent absorption and fluorescence experiments. 


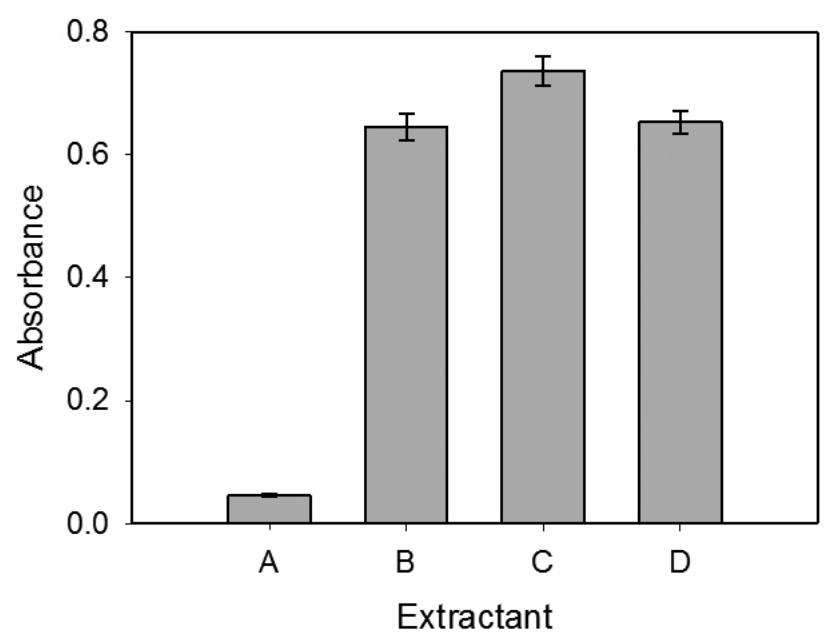

Figure 3 The absorption of curcumin in different extractant extraction. The absorbance of curcumin (A), the absorbance of curcumin after extracted by $[\mathrm{Omim}]\left[\mathrm{BF}_{4}\right](\mathrm{B})$, the absorbance of curcumin after extracted by [Hmim] $\left[\mathrm{PF}_{6}\right](\mathrm{C})$, the absorbance of curcumin after extracted by $[\mathrm{Omim}]\left[\mathrm{PF}_{6}\right]$ (D). Each value represents the average of 5 different measurements and the standard deviation is indicated as error bars. The concentration of curcumin was $184 \mathrm{ng} /$ $\mathrm{mL} ; \mathrm{pH}, 4.0$.

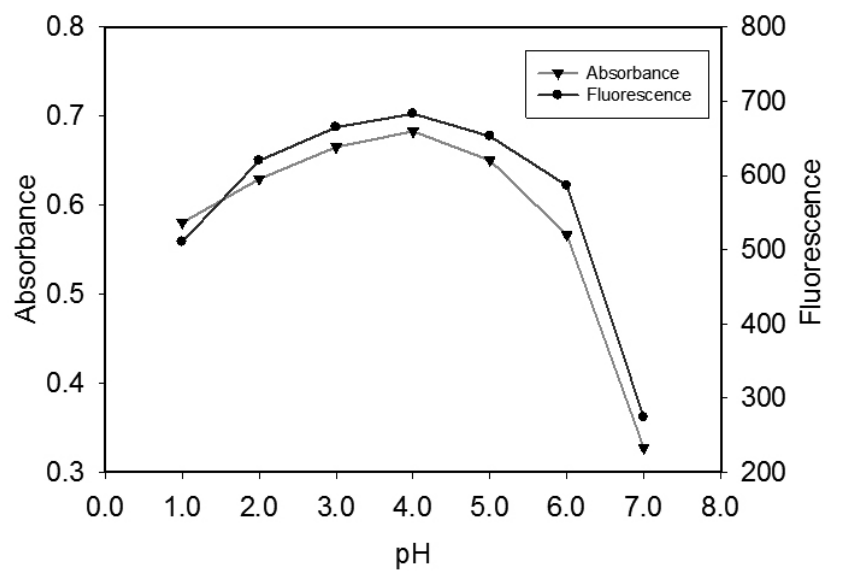

Figure 4 Impact of $\mathrm{pH}$ on absorbance and fluorescence intensity. The maximum absorbance and fluorescence intensity was obtained at $\mathrm{pH}$ 4.0. Experiment conditions: curcumin concentration, 18.4 and $9.2 \mu \mathrm{g} / \mathrm{mL}$ (spectrophotometry and spectrofluorometry determination, respectively); $[\mathrm{Hmim}]\left[\mathrm{PF}_{6}\right], 200 \mu \mathrm{L}$; extraction time, $5 \mathrm{~min}$; dispersive temperature, $70{ }^{\circ} \mathrm{C}$; centrifugation time, $8 \mathrm{~min}$.

\section{Diffusion Temperature}

Temperature is the key parameter in the extraction process which affects the mass transfer rates of analytes and increase the contact area between IL and aqueous solution. Hence, temperature was investigated in detail in the temperature range of $50-95{ }^{\circ} \mathrm{C}$ with the thermostatic time of $5 \mathrm{~min}$. The results are shown in Figure 5, the absorbance and fluorescence intensity increases before the temperature reaches $70{ }^{\circ} \mathrm{C}$ and then decreases with the further increase of temperature. The lower recoveries at lower temperature may be due to the poor performance of IL dispersion, the low diffused rate of curcumin, and the high temperature, which could cause the loss of settled phase and consequently result in the reduction of extraction efficiency. Therefore, the temperature was fixed at $70{ }^{\circ} \mathrm{C}$.

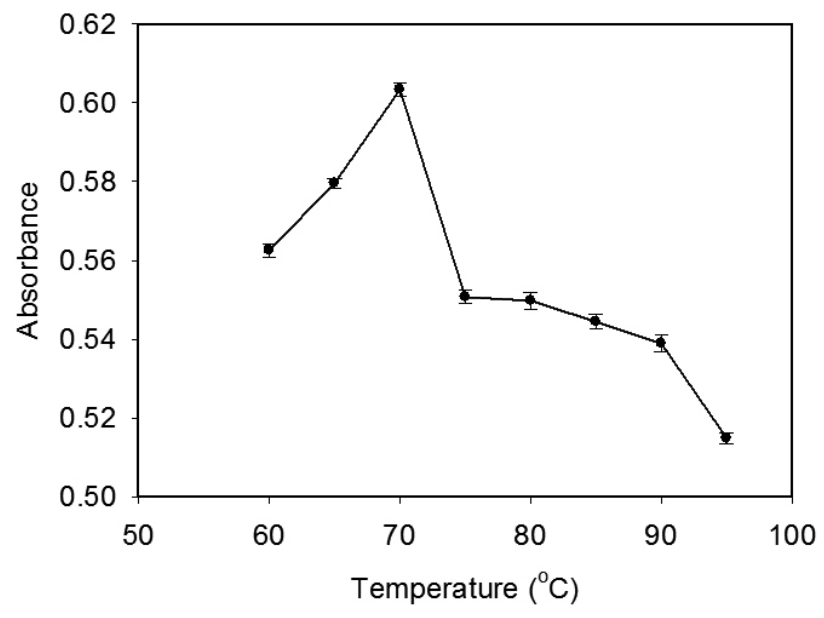

Figure 5 Effect of the diffusion temperature. Each value represents the average of 5 different measurements and the standard deviation is indicated as error bars. Experiment conditions: curcumin concentration, $18.4 \mu \mathrm{g} / \mathrm{mL}$; $[\mathrm{Hmim}]\left[\mathrm{PF}_{6}\right], 200 \mu \mathrm{L}$; extraction time, $5 \mathrm{~min} ; \mathrm{pH}, 4.0$; centrifugation time, 8 min; and drying temperature and time, $70{ }^{\circ} \mathrm{C}$ and $60 \mathrm{~min}$; constant volume to $0.3 \mathrm{~mL}$ with methanol.

\section{Diffusion Time}

In TAIL-DLPME, the diffusion time is defined as the time interval between the centrifuge tube being placed into the water bath and the ice bath. Diffusion time was investigated in detail in the time range of $1 \mathrm{~min}$ to $15 \mathrm{~min}$ at $70{ }^{\circ} \mathrm{C}$. The absorbance increased before the diffusion time reached $5 \mathrm{~min}$ and then achieved equilibrium. Thus, the diffusion time was maintained at $5 \mathrm{~min}$ in all cases.

\section{Effect of extraction time}

Employing the shortest equilibration time is desirable to achieve the best extraction efficiency of target analytes for all the extraction methods. For $[\mathrm{Hmim}]\left[\mathrm{PF}_{6}\right]$, extraction time is defined as the time interval between the centrifuge tube being placed into the ice bath and the start of centrifugation. The dependence of extraction efficiency upon extraction time was studied within the time range of 1-12 min. The maximum absorbance and fluorescence intensity was obtained at $5 \mathrm{~min}$ and reaches a constant value when the extraction time exceeds $5 \mathrm{~min}$. Therefore, the extraction time was kept at $5 \mathrm{~min}$ in all cases.

Centrifugation time

Centrifugation time is also an important parameter in the separation of IL from the water phase. A centrifugation time in the range of 2-15 $\mathrm{min}$ at the rate of $3500 \mathrm{rpm}(1684 \times g)$ was investigated. A very short centrifugation time cannot ensure satisfactory phase separation while a longer centrifugation time causes the IL to again liquefy to the water phase, which led to the dissolving of parts of $[\mathrm{Hmim}]\left[\mathrm{PF}_{6}\right]$ phase and the loss of sensitivity. The maximum absorbance and fluorescence intensity was obtained at $8 \mathrm{~min}$. When the centrifugation time was shorter or longer than $8 \mathrm{~min}$, the absorbance and fluorescence intensity slowly decreases. Therefore, 8 min was chosen as optimum.

Calibration graph and sensitivity

Under the optimized experimental conditions, standard calibration curves of curcumin were constructed by plotting the absorbance and fluorescence intensity versus concentration at $\square=422 \mathrm{~nm}$ and $\square_{\mathrm{em}}=499 \mathrm{~nm}$. The linear regression data are listed in Table 1 . The extraction efficiency and concentration of curcumin exhibited a linear relationship of absorption in the range of 18.4 $\mathrm{ng} / \mathrm{mL}$ to $494 \mathrm{ng} / \mathrm{mL}$, with a determination coefficient of 0.9997 and detection limit of $6.1 \mathrm{ng} / \mathrm{mL}$. The liner relationship of fluorescence was found in the range of $0.050 \mathrm{ng} / \mathrm{mL}$ to $120.1 \mathrm{ng} / \mathrm{mL}$, with a determination coefficient of 0.9995 and detection limit of $0.002 \mathrm{ng} / \mathrm{mL}$. 
Table 1. The performance characteristics of the proposed method.

\begin{tabular}{|c|c|c|}
\hline Parameters & UV-vis & Fluorescence \\
\hline linear regression equations & $\mathrm{A}=4.140 \mathrm{C}(\mu \mathrm{g} / \mathrm{mL})-0.0275$ & $\mathrm{~F}=8189 \mathrm{C}(\mu \mathrm{g} / \mathrm{mL})+16.22$ \\
\hline Linear relationship $(\mathrm{ng} / \mathrm{mL})$ & $18.4 \sim 494$ & $0.050 \sim 120.1$ \\
\hline Limit of detection (LOD) (ng/mL) & 6.1 & 0.002 \\
\hline Limit of quantitation (LOQ) $(\mathrm{ng} / \mathrm{mL})$ & 18.4 & 0.007 \\
\hline Correlation coefficient $\left(\mathrm{R}^{2}\right)$ & $0.9997(n=8)$ & $0.9995(n=8)$ \\
\hline S.D. of reagent blanks $\left(\mathrm{S}_{0}, \mathrm{n}=11\right)$ & 0.00454 & 0.68568 \\
\hline
\end{tabular}

As shown in Table 2 (the LOD of this method is obtained by experiment), spectrofluorometry through IL extraction is sensitive compared with previously reported methods, including HPLC and capillary electrophoresis with amperometric detection (CE-AD). The proposed spectrophotometry method has higher sensitivity than the UV $-\beta-\mathrm{CD}$ method. Compared with the traditional separation techniques, and does not require large amounts of toxic organic solvents; compared with other proposed spectrofluorometry and spectrophotometry methods, this method has the higher sensitivity; compared with the metal complex, which does not require a large number of heavy metals, reducing heavy metal pollution; and using spectrofluorometry and spectrophotometry can greatly reduced the use of costly equipment and expenses in 'NMR, HPLC and mass spectrometry methods, based on the simple equipment they need, this method more likely to be widely used in real life. Thus, the obvious advantages of the proposed method include high sensitivity, low chemical consumption, simple equipment, less solvent waste, low environmental pollution, and use of recyclable IL.

Table 2. Comparison with other proposed methods.

\begin{tabular}{|c|c|c|c|}
\hline Technique & Linear range (ng/mL) & $\mathrm{LOD}(\mathrm{ng} / \mathrm{mL})$ & Reference \\
\hline $\mathrm{UV}-\beta-\mathrm{CD}$ & $0 \sim 1.5 \times 10^{4}$ & 76.0 & 21 \\
\hline Nitrile fluorimetric method & $0.27 \sim 1.5 \times 10^{3}$ & 0.08 & 15 \\
\hline Fluorescence $-\mathrm{Cu}$ (II) probe resonance light scattering technique & $400 \sim 6.0 \times 10^{4}$ & 70.0 & 18 \\
\hline Fluorescence-Eu $\mathrm{Eu}^{3+}$-tryptophan complex & $3.7 \sim 4.42 \times 10^{4}$ & 0.33 & 36 \\
\hline Fluorescence-yttrium(III) - curcumin - sodium dodecyl benzene sulfonate & $0.74 \sim 180,180 \sim 2.95 \times 10^{3}$ & 0.16 & 37 \\
\hline CE-AD & $1.1 \times 10^{3} \sim 2.6 \times 10^{5}$ & 0.011 & 12 \\
\hline general HPLC-UV method & $50 \sim 5.0 \times 10^{3}$ & 18.4 & 11 \\
\hline LC-MS/MS & $10 \sim 2000$ & 10.0 & 16 \\
\hline HPLC Method & $62.5 \sim 2.0 \times 10^{3}$ & 20.8 & 38 \\
\hline CCT-DLLME system & $50 \sim 1.0 \times 10^{5}$ & 28 & 39 \\
\hline${ }^{1} \mathrm{H}$ NMR & $2.0 \times 10^{5} \sim 5.0 \times 10^{6}$ & 2000 & 17 \\
\hline LC-MS/MS & $10 \sim 200$ & 1.00 & 17 \\
\hline \multirow{2}{*}{$\frac{\mathrm{UV}-\mathrm{vis}}{\text { Fluorescence }}$} & $18.4 \sim 4.9 \times 10^{2}$ & 6.10 & This work \\
\hline & $0.050 \sim 120.1$ & 0.002 & This work \\
\hline
\end{tabular}

Effect of Foreign Ions

A systematic study was carried out on the effects of the foreign ions on the determination of $0.11 \mu \mathrm{g} / \mathrm{mL}$ of curcumin. A $1.1 \times 10^{4} \mu \mathrm{g} / \mathrm{mL}$ level of each potentially interfering ion was tested first. If interference occurred, the ratio was reduced progressively until interference ceased. The tolerance level was defined as an error not exceeding $\pm 5 \%$ in the determination of curcumin. The results are summarized in Table 3. It can be seen that most of the foreign ions (not includes $\mathrm{Cr}_{2} \mathrm{O}_{4}^{2-}$, $\mathrm{NO}_{2}{ }^{-}$and $\mathrm{Fe}^{3+}$ ) have no detrimental effect on the determination. This fact indicates good selectivity of the method to determine the curcumin.

Table 3. Tolerance levels of foreign substances in determining $(0.11 \square \mathrm{g} / \mathrm{mL})$ of Curcumin. $(<5 \%$ error $)$.

\begin{tabular}{|c|c|}
\hline Foreign ions & Tolerance level $(\mu \mathrm{g} / \mathrm{mL})$ \\
\hline $\mathrm{Na}^{+}, \mathrm{K}^{+}, \mathrm{Cl}^{-}$ & $1.0 \times 10^{4}$ \\
\hline L-Glutamate, Glucose, Lysine, Glycin, Caramel, I- $\mathrm{Ni}^{+}, \mathrm{Ba}^{2+}, \mathrm{NH}_{4}^{+}, \mathrm{Ac}^{-}, \mathrm{H}_{2} \mathrm{PO}_{4}^{-}, \mathrm{SO}_{4}{ }^{2-}, \mathrm{NO}_{3}{ }^{-}, \mathrm{Pb}^{2+}, \mathrm{Sr}^{2+}$ & $1.0 \times 10^{3}$ \\
\hline $\mathrm{EDTA}, \mathrm{Sucrose}, \mathrm{Zn}^{2+}, \mathrm{Mn}^{2+}, \mathrm{Sn}^{2+}, \mathrm{Cd}^{2+}$ & $7.5 \times 10^{2}$ \\
\hline $\mathrm{Mg}^{2+}, \mathrm{CO}_{3}{ }^{2-}, \mathrm{Cu}^{2+}$ & $3.0 \times 10^{2}$ \\
\hline $\mathrm{Cr}_{2} \mathrm{O}_{4}{ }^{2-}$ & 20 \\
\hline $\mathrm{Fe}^{3+}, \mathrm{NO}_{2}{ }^{-}$ & 4 \\
\hline
\end{tabular}

Condition: $\mathrm{pH}, 4.0 ;[\mathrm{Hmim}]\left[\mathrm{PF}_{6}\right], 200 \mu \mathrm{L}$; diffusion temperature, $70{ }^{\circ} \mathrm{C}$; extraction time, $5 \mathrm{~min}$; centrifugation time, 8 min; drying temperature and time, 70 ${ }^{\circ} \mathrm{C}$ and $60 \mathrm{~min}$; constant volume to $0.3 \mathrm{~mL}$ with methanol. 
Table 4. Determination of curcumin in curry products.

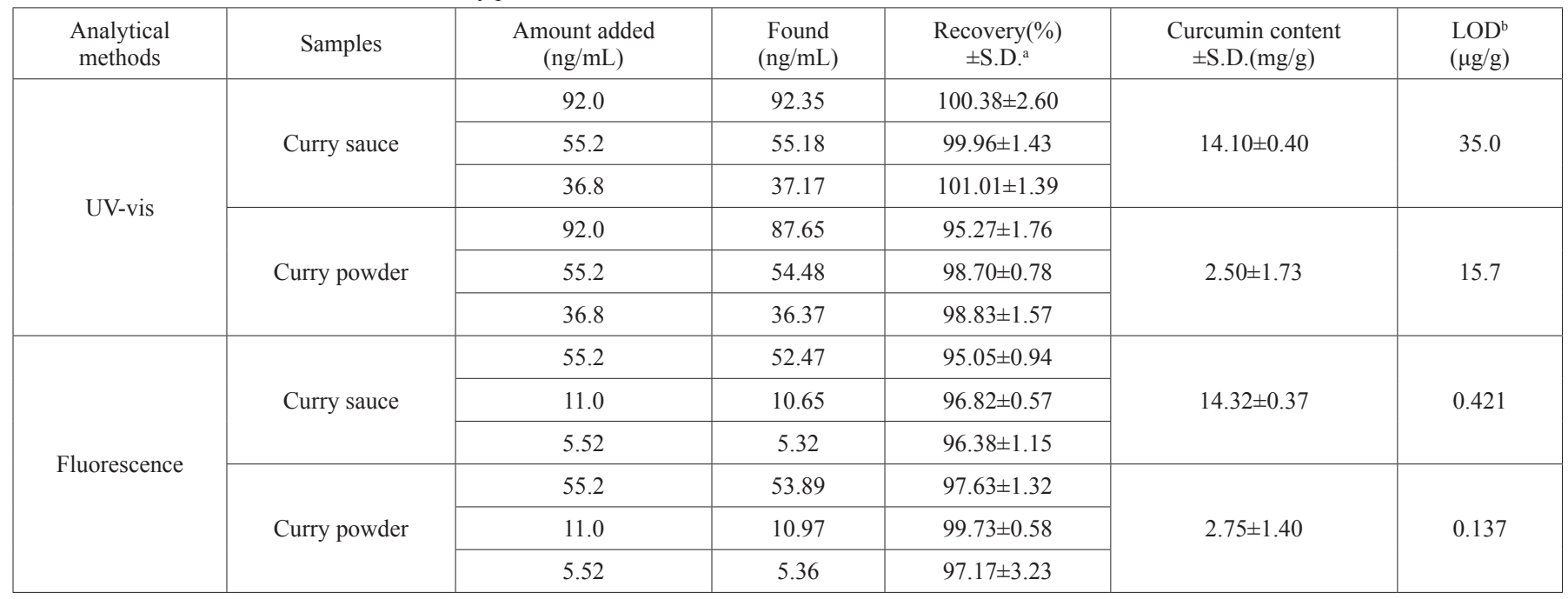

${ }^{a}$ Average of five determinations. ${ }^{\mathrm{b}}$ The detection limit of curcumin content in curry products

\section{Analytical applications}

The proposed method was used for the determination of curcumin in curry sauce or curry powder. Five replicate determinations were conducted using three different concentrations and the results were obtained in Table 4 (the LOD of curcumin content in curry products is obtained by calculation). To check the validity of the proposed method, the standard addition method was conducted by adding the curcumin to curry sauce and curry powder. The content of curcumin in curry sauce were $14.10 \pm 0.40$ and $14.32 \pm 0.37 \mathrm{mg} / \mathrm{g}$ when using the spectrophotometry and spectrofluorometry, the content of curcumin in curry powder were $2.50 \pm 1.73$ and $2.75 \pm 1.40 \mathrm{mg} / \mathrm{g}$ when using the spectrophotometry and spectrofluorometry. The recovery of curcumin was calculated by comparing the concentration obtained from the (spiked) mixtures with those of the pure curcumin. Table 4 shows the recovery study of the curcumin, the recoveries were all in the range of $95 \%$ to $105 \%$, and this method is proved have a good repeatability. Thus, the preconcentration method was successfully used to extract curcumin in curry products.

\section{CONCLUSIONS}

The present study validated a novel, environment-friendly, and sensitive method for the determination of curcumin based on ILs, the result shows that $[\mathrm{Hmim}]\left[\mathrm{PF}_{6}\right]$ exhibited better extraction recovery and ILs considerably increased the fluorescence for curcumin. Conditions for curcumin extraction were also investigated and optimized. Under optimum conditions, the spectrofluorometry method is sensitive compared with the HPLC and CE$\mathrm{AD}$ methods. The sensitivity of the proposed spectrophotometry method is also higher than that of other spectrophotometry methods. The influence of foreign ions (except $\mathrm{Cr}_{2} \mathrm{O}_{4}^{2-}, \mathrm{NO}_{2}^{-}$and $\mathrm{Fe}^{3+}$ ) can be ignored in this method. Compared with using large-scale organic solvents, using ILs as extractant can reduce exposure to toxic solvents, environmental pollution, and the cost of conventional extraction procedures. The preconcentration method was successfully used to extract curcumin in curry products.

\section{ACKNOWLEDGEMENTS}

This work was supported by the National Natural Science Foundation of China (No. 21171110) and the Research Fund for the Doctoral Program of Higher Education of China (No.20091404110001). Helpful suggestions by anonymous referees are also gratefully acknowledged.

\section{REFERENCES}

1. M.T. Huang, Y.R. Lou, W. Ma, H.L. Newmark, K.R. Reuhl, A.H. Conney, Cancer Res. 54, 5841, (1994)

2. C.F. Chignell, P. Bilski, K.J. Reszka, A.G. Motten, R.H. Sik, T.A. Dahl, Photochem. Photobiol. 59, 295, (1994)
3. J. Shi, Z.X. Wang, Y.P. Tian, X.X. Zheng, Zhongcaoyao (in Chinese) 22, $139,(1997)$

4. A. Janssen, T. Gole, Chromatographia 18, 546, (1984)

5. H.H. Toennesen, A.L. Grislingaas, J. Karlsen, Z. Lebens. Unters. Forsch. 193, 548, (1991)

6. A.P. Gupta, M.M. Gupta, S. Kumar, J. Liq. Chromatogr. Relat. Technol. 22, 1561, (1999)

7. M.J. Ansari, S. Ahmad, K. Kohli, J. Ali, R.K. Khar, J. Pharm. Biomed. Anal. 39, 132, (2005)

8. R.M. Smith, B.A. Witowska, Analyst 109, 259, (1984)

9. Y. Pak, R. Patek, M. Mayersohn, J. Chromatogr. B 796, 339, (2003)

10. D.D. Heath, M.A. Pruitt, D.E. Brenner, C. Rock, J. Chromatogr. B 783, 287, (2003)

11. R.S.P. Singh, U. Das, J.R. Dimmock, J. Alcorn, J. Chromatogr. B 878, 2796, (2010)

12. X.H. Sun, C.L. Gao, W.D. Cao, X.R. Yang, E.K. Wang, J. Chromatogr. A 962, 117, (2002)

13. L.A. May, E. Tourkina, S.R. Hoffman, T.A. Dix, Anal. Biochem. 337, 62, (2005)

14. F. Jasim, F. Ali, Microchem. J. 46, 209, (1992)

15. D.A. Navas, M.C. Ramos Peinado, Food Chem. 40, 56, (1992)

16. V. Kakkara, S. Singhb, D. Singlab, S. Sahwneyc, A.S. Chauhanc, G. Singhc, I.P. Kaura, J. Chromatogr. B 878, 3427, (2010)

17. A.C. Görena, S. Çıkrıkçı, M. Çergelb, G. Bilsela, Food Chem. 113, 1239 , (2009)

18. Z. Chen, L. Zhu, T. Song, J. Chen, Z. Guo, Spectrochim. Acta A 72, 518, (2009)

19. F. Jasim, F. Ali, Microchem. J. 38, 106, (1988)

20. J.J. Nevado, C.G. Cabanillas, A.M. Salcedo, Talanta 41, 789, (1994)

21. B. Tang, L. Ma, H.Y. Wang, G.Y. Zhang, J. Agric. Food Chem. 50, 1355, (2002)

22. D. Han, K.H. Row, Molecules. 15, 2405, (2010)

23. J. Ma, X. Hong, J. Environ. Manage. 99, 104, (2012)

24. H. Wu, L.B. Zhang, L.M. Du, Talanta 85, 787, (2011)

25. Q.X. Zhou, H.H. Bai, G.H. Xie, J.P. Xiao, J. Chromatogr. A 1177, 43 , (2008)

26. N.L. Lancaster, P.A. Salter, T. Welton, G.B. Young J. Org. Chem. 67, $8855,(2002)$

27. C. Rocaboy, F. Hampel, J.A. Gladysz, J. Org. Chem. 67, 6863, (2002)

28. H.M. Zerth, N.M. Leonard, R.S. Mohan, Org. Lett. 1, 55, (2003)

29. F. Liu, X. Cui, S.Yu, Z. Li, X. Ge, J. Appl. Polym. Sci. 114, 3561, (2009)

30. F. Kamarei, H. Ebrahimzadeh, Y. Yamini, Talanta 83, 36, (2010)

31. R.S. Zhao, X. Wang, J.P. Yuan, S.S. Wang, C.G. Cheng, Chin. Chem. Lett. 22, 97, (2011)

32. H.F. Zhang, Y.P. Shi, Talanta 82, 1010, (2010) 
33. L.B. Zhang, H. Wu, L.M. Du, G.Q. Wang, Y.X. Chang, Anal. Methods 4, $1117,(2012)$

34. A.M. Powe, K.A. Fletcher, N.N. St Luce, M. Lowry, S. Neal, M.E. McCarroll, P.B. Oldham, L.B. McGown, I.M. Warner, Anal. Chem. 76, 4614, (2004)

35. H.H. Toennesen, J.Z. Karlsen, Lebensem. Unters. Forsch. 180, 132,
(1985)

36. F. Wang, W. Huang, J. Pharm. Biomed. Anal. 43, 393, (2007)

37. F. Wang, W. Huang, Y.W. Wang, J. Lumin. 128, 110, (2008)

38. G.K. Jayaprakasha, L.J.M. Rao, K.K. Sakariah, J. Agric. Food Chem. 50, $3668,(2002)$ 